\title{
School and community partnership in promoting elementary education: A case study of union council Chountra, Rawalpindi, Pakistan
}

\author{
Malik Ghulam Behlol | Faiza Masood* \\ Department of Education, Fatima Jinnah Women University, Rawalpindi, Pakistan. \\ *Correspondence Emails: faiza.masood@fjwu.edu.pk | faiza.masood1985@gmail.com
}

\begin{abstract}
The local communities and School Councils (SC) play a significant role in supporting the schools for successful and effective learning at the elementary level. This study examines the extent of community-school partnership in improving the functioning of elementary schools, and community development through the agency of SC. The main research question of the study was, how school and community mutually guide, interact and support each other for solving the burning issues faced to primary schools in their effective functioning. The case study method with survey technique was applied to conduct this study. Thirteen elementary schools located in Union Council (UC) Chountra, a Sub-Tehsil of district Rawalpindi were taken as an integrated case. The quantitative and qualitative data was gathered through a checklist with five point Likert scale, and a semi-structured interview which were corroborated for analysis to draw findings and conclusions. Analysis revealed that schools are not fully successful in increasing the retention rate for the universalization of elementary education due to poor teachers' commitment, unattractive school buildings, corporal punishment, and parents' deteriorating trust in public schools. Participation of community through the agency of SC in academic, administrative, logistic matters of schools is almost non-functional.
\end{abstract} Article History

Received:

February 9, 2021

Last Revised:

April 28, 2021

Accepted:

May 2, 2021

Published:

June 18, 2021

Keywords: local community, school community, elementary schools, primary schools, schoolcommunity partnership, school council, students enrolment, students dropout.

How to Cite: Behlol, M. G. \& Masood, F. (2021). School and community partnership in promoting elementary education: A case study of union council Chountra, Rawalpindi, Pakistan. Liberal Arts and Social Sciences International Journal (LASSIJ), 5(1), 301-319. https://doi.org/10.47264/idea.lassij/5.1.20

Publisher's Note: IDEA PUBLISHERS (IDEA Journals Group) stands neutral with regard to the jurisdictional claims in the published maps and the institutional affiliations.

Copyright: (C) 2021 The Author(s), published by IDEA PUBLISHERS (IDEA Journals Group). This is an Open Access article published under the Creative Commons Attribution-NonCommercial 4.0 International License (http://creativecommons.org/licenses/by-nc/4.0/) 


\section{Introduction}

Communities are primary educators which influence a child's growth in terms of learning and development during the school years and later period of life. Effective parental and Community Partnership (CP) with schools, facilitate utilization of scattered and multi-dimensional communal resources for the wellbeing, education, and proper development of a child (Gregoric, 2013; Epstein, 2010; Okenwa \& Igbo, 2013; Aguba, 2009; Okwor, 2008; Cole, 2007). CP in primary school's academic, financial, and administrative management promotes social capital, greater assistance in academic activities, contribution in school committees, increase in fundraising, provision of logistics facilities (transportation, building, classroom equipment's, furniture, and academic expertise), and address several problems (Tolbert \& Theobald, 2006), Schools with a low level of CP show poor results and decision making, failure in developing inclusive plans (Prew, 2009; Tolbert \& Theobald, 2006). Henderson and Mapp (2002) highlighted when schools build a partnership with families and parents, they tend to get success in improving students' achievements, and when families and communities make schools accountable, the school district brings positive change in policy, practice, and resources.

Usually, community participation in the affairs of schools through School Councils/Parent Teacher Association/ School Management Committees, etc. provides answerable school policy forum to parents and students to interact and share ideas with the management of a school (Habib, 2014; Ayub, 2001). Research studies reveal that the ties between Schools and Communities in the majority of developing countries of the world are not functional. Lack of $\mathrm{CP}$ in primary school functioning negatively influences the quality of education and consequently enhances the rate of dropout. As a result, many primary-age children are out-ofschool in the majority of Asian and African countries (Okenwa \& Igbo, 2013; Okwor, 2008; Cole, 2007). According to the 2017 Global Education Monitoring report, there are 16 million children who do not have access to primary education, and in sub-Sahara Africa, only $59 \%$ of children complete their primary education. According to UNESCO (2007), 50\% of primary school students worldwide even don't know how to read and write.

Parental involvement in children's education was effective and functional in Madrassa (Muslim schools) and Petshala (non-Muslims schools) before the arrival of the British in the subcontinent. Well-off community members provide financial assistance to madrassa and Petshala and also realize the importance of education. In this context, the role of the community did exist in the running of educational institutions (Sajjad, 2006). Democratization of education and provision of equal opportunity of basic education for all citizens has put extraordinary pressure on the professionals and also on the national exchequer. Consequently, parents are invited to become more involved with schools as volunteers, helpers in classrooms, and as members of school boards and committees.

CP in schools formally promulgated in 1994 in Pakistan via implementation of Social Action Plan (SAP) in the form of School Management Committees (SMCs). With the formulation of new education policy 2009, School Council (SC) replaced SMCs with new guidelines and responsibilities: monitoring the performance of school teachers, use of school fuwhnds, raising local resources, purchasing furniture, enhancement in enrolment, and reduction in dropouts, develop, implement, monitor and review the school plan, collaborate with the other school advisory committee; conduct annual needs assessment; establish an annual meeting calendar; schedule training for members to learn about their roles. Khan (2003) discovered that to make participation effective in primary schools; public sector reforms are needed to be carried out to 
build a framework of relationships among parents, teachers, and government officials that is missing in schools. The study also revealed that SC in majorities of schools exists on paper and severely lacking in performing their academic, administrative, supportive role for the effective functioning of primary schools in District Rawalpindi (Khan, 2003).

Ahmad and Ullah (2014) revealed that the extent of CP in the provision of school plants in public primary, secondary schools in District Rawalpindi is low. Community representatives also by and large are not contributing positively to the functioning of school activities and take it merely a formal activity. Lack of awareness, in-time communication, democratic and accountable school policy are the major challenges that affect the performance of CP in schools in Pakistan (Habib, 2014; Ahmed \& Obaid-Ullah, 2014; Sajjad, 2006; Hussain \& Naz, 2013). Performance of SCs in girls' primary schools located in Rawalpindi district is also found worse about parenting skills, in assisting families about child-rearing, understanding child and adolescent development, and setting home conditions that support children. Parents play a significant role in helping primary age children to reach school in time, and also teachers may guide families to support the child in homework is almost missing on the part of schools and community in the primary schools of Rawalpindi district (Bibi, 2011).

Communication between home-to-school and school-to-home is also nonexistent because of parents' engagements in job and agriculture activities; and also on the perceptions of teachers that communication of school policies and practices to parents may create administrative and official problems. In this way, the learning problems of the students that demand their participation in form of continuous communication flow are missing (Sajjad, 2006). Families and parents may grant volunteering services in an academic, administrative and logistic matter to support the school that was also found nowhere. This disconnect between school and community is also affecting the performance of primary schools located in the Rawalpindi district. The reasons for disconnection between community and school have not been focused On in the previous studies.

The above-mentioned scenario demanded to dig deep by choosing the convenient area for studying the extent and problems of community-school partnership in improving the functioning of elementary schools through the agency of SC. It will be a step forward to increase the retention rate of students, improving literacy, and provision better places at schools for the teacher to work. The main question of the study is how do school and community partnership support each other in dealing with the challenges faced by primary schools in their effective operation?

\section{Theoretical framework}

Epstein (2010) presented the framework for school, family, and community partnership consisting of six factors: parenting, communication, volunteering, learning at home, decision making, and collaborating with the community. The framework is on the conflation of activities that together represent effective parental involvement in their children's schooling that is also used by Adams et al., (2009). In this study, the context of parental involvement means a situation in which parents are perceived as active partners in the process of educating their children. It is awareness of, and achievement in, school work, an understanding of the interaction between parenting skills and learner success in schooling, and a commitment to consistent communication with educators about learner progress (Makgopa \& Mokhele, 2013; Mncube, 2010). Similarly, according to Domina (2005) and Hoover-Dempsey et al. (2001) 
parents' participation is helping their children with homework, holding parent-teacher interviews, conducting parent nights, having special consultations on the child's problems, teaching for understanding, volunteering in classroom and outside activities and holding parent councils. Empirical evidence reveals an important link between parental involvement and the educational achievement of children based on the Episteme framework (Sheng, 2012; Studsrod \& Bru, 2009; Symeou, 2007; Damle, 2006; Lee \& Bowen, 2006).

2.1. Parenting: Schools need to help families and assist them with those parenting skills that may guide them to know better about their child, understand the developmental needs of the child and also of adolescence. Schools assist families so that they create such an environment at home where their children can learn better.

2.2. Communicating: Schools need to assist families and communicate with them to share school programs and their children's progress. The creation of two-way communication is necessary between school and home.

2.3. Volunteering: Schools enable community members to volunteer and participate in training activities and to support the school for the betterment of students.

2.4. Learning at Home: Teachers can design homework, tasks, and activities for students so that they can learn at home. Parents need to be encouraged so that they get involved with their children in academic learning at home.

2.5. Decision Making: School councils, improvement teams, school community committees, and parent organizations need to develop through which parents need to be involved in decision-making regarding school governance and advocacy.

2.6. Collaborating with the Community: School and community need to coordinate with each other, especially in terms of resource provision to each other including business, cultural and civic organizations.

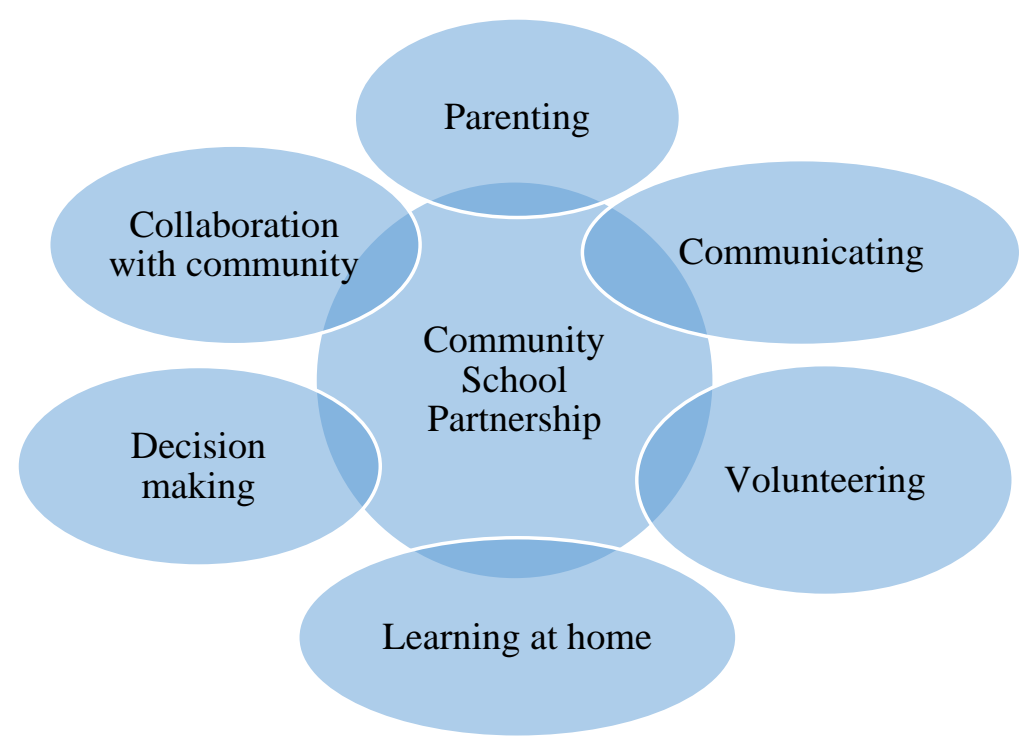

Figure 1: Theoretical framework

\section{Methodology of the study}

\subsection{Method of the study}

An integrated case study with a survey method was applied to investigate the problems and the extent of community and school partnership in the functioning of elementary schools through 
the agency of SC. According to Cresswell (2013), descriptive-survey research defines what exists in a natural setting. Mix method was used to gather data to address the research questions of the study relating to the community and school partnership.

\subsection{Design and instruments}

There were two phases in the study; in the first phase, the researcher collected quantitative data by using five points Likert scale and checklist. The rating scale is attached in the annexure. It was also validated by the experts and pilot tested before administration. Reliability indicates the consistency of the relationship between items of the scale. Reliability of individual factors identified that each category had a different number of items with a high level of consistency (0.92). A checklist was used to examine the building condition, student-teacher ratio, dropoutrate, and missing facilities. It was finalized after studying the checklist used by Zepatou et al. (2016), and also consultation with the working teachers.

Based on quantitative results, the researcher decided to conduct semi-structured interviews of teachers and community leaders to crosscheck the quantitative data and comprehend the holistic picture of elementary schools and community partnerships. A formal letter on the behalf of the Vice-Chancellor and three follow-up visits were made to get permission for the collection of data from Executive Education Officer Rawalpindi. The volunteer was trained to visit schools to collect the data.

\subsection{Population and participants}

The target population of the study was the heads and teachers of primary schools, notable community members, and parents of the students studying in the primary schools of UC Chountra. One UC (Chountra) as an integrated case out of 120 UCs of Tehsil Rawalpindi was selected for the interventions of the study. Reasons for the selection of UC were that it is a backward area of the Tehsil, and the researcher also belongs to this area that may help in getting the support of the schools and community to carry out the study. The notable people of UC are quite familiar with the researcher because of living in the area of parents and grandparents for a long time and also primary schooling in the same UC.

A senior staff member who was designated by head of the school filled the checklist. There were thirteen schools in the UC and in this way the data relating to Checklist was collected in five visits. 56 teachers and 20 community members/parents responded on the rating scale. Teachers were the head and most senior members of the school. The academic qualification of teachers was from graduation (14 Years) to MA (16 Years) with a Certificate of Teaching or B.ED or M.ED as a professional qualification. Five teachers and five community members were interviewed to cross-check the data. Two of the teachers were BA, B.ED, two were MA, B.ED and one of them was MA, M.Ed. Gender-wise, there were three male and two female teachers. Male community members were interviewed having different qualifications, ages, and professions.

\section{Analysis of the data}

Quantitative data were analyzed by calculating frequencies, percentages, and mean. To determine the effectiveness/significance of the statements on the Likert scale, the cut-off score method was used. The qualitative data was collected with semi-structured interviews were 
recorded, transcribed, coded, and refined. Trustworthiness was checked by sending back the interview script to the respondents again. Thematic analysis was done for the qualitative data. The thematic analysis aimed to identify themes in the study which are relevant to the study and interest the researcher (Maguire \& Delahunt, 2017; Clarke \& Braun, 2013).

\subsection{Demographic information and school profile}

The data was gathered by using a Checklist regarding school building, classroom situation, school furniture, computer facilities, basic needs facilities, use of learning material for teaching, and learning environment. Frequencies and percentages were calculated and presented in the form of tables and graphs. The semi-structured interviews were conducted with five teachers and five community members and audio recorded. The duration of each interview was 30-35 minutes.

Table-1: Demographic information about schools (UC Chountra)

\begin{tabular}{|c|c|l|c|c|c|}
\hline S.\#. & $\begin{array}{c}\text { Establishment } \\
\text { Year }\end{array}$ & School Name & $\begin{array}{c}\text { Number of } \\
\text { teachers }\end{array}$ & $\begin{array}{c}\text { Number of } \\
\text { students }\end{array}$ & $\begin{array}{c}\text { Number of } \\
\text { private schools }\end{array}$ \\
\hline 1 & $1800-1900$ & $\begin{array}{l}\text { GBES Chountra } \\
\text { 1804(1989) }\end{array}$ & 16 & 347 & 3 \\
& & GBPS Bhall 1917 (1988) & 6 & 164 & 3 \\
\cline { 3 - 6 } 2 & $1901-1947$ & GPS Adhawal 1927 (2007) & 5 & 128 & 7 \\
\hline \multirow{3}{*}{3} & \multirow{3}{*}{$1948-1970$} & GGPS Mohra 1962 (2012) & 7 & 118 & 2 \\
\cline { 3 - 6 } & & GPS Salmon 1967 & 6 & 214 & 1 \\
\cline { 3 - 6 } & & GPS Chak Saghoo 1970 & 3 & 83 & Nil \\
\hline \multirow{4}{*}{4} & \multirow{3}{*}{$1971-2000$} & GBPS Mohra 1972 & 2 & 56 & 1 \\
\cline { 3 - 6 } & & GPS Parri 1973 & 4 & 39 & Nil \\
\cline { 3 - 6 } & & GGPS Chokar 1979 & 3 & 62 & Nil \\
\cline { 3 - 6 } & & GPS Dhok Mirza 1980 & 4 & 74 & 2 \\
\cline { 3 - 6 } & & GPS Ghalwal 1987 (1991) & 2 & 27 & 2 \\
\cline { 3 - 6 } & & GPS Hoon & 5 & 90 & 77 \\
\cline { 3 - 6 } & & GES Hoon & 72 & 1479 & 22 \\
\hline 5 & $1800-2017$ & & & & \\
\hline
\end{tabular}

The data revealed that there were 13 schools, 72 teachers, 1479 students in UC Chountra along 22 private schools. The first school in the UC Chountra was established in 1904. The teacherstudent ratio was 1:21.

Table-2: Overall Teacher-student and teacher school ratio

\begin{tabular}{|c|c|c|c|c|}
\hline Schools & Teachers & Students & Teacher-student ratio & Teacher school ratio \\
\hline 13 & 72 & 1479 & $1: 21$ & $1: 6$ \\
\hline
\end{tabular}

The figure-1 shows the percentage of responses regarding the condition of the school building in UC Chountra. $81.3 \%$ of respondents said that there is no separate office for the head of school and $67 \%$ said that toilets are not in working condition, $37.5 \%$ respondents viewed that there is a lack of open spaces, $31.3 \%$ respondents expressed the unavailability of wired boundary wall in their school, $25 \%$ held the opinion that school entrance is not identifiable, $18.8 \%$ respondents agreed that the school building is declared dangerous and $62.5 \%$ viewed no staffroom for teachers. 
Figure-1: Building profile of UC Chountra

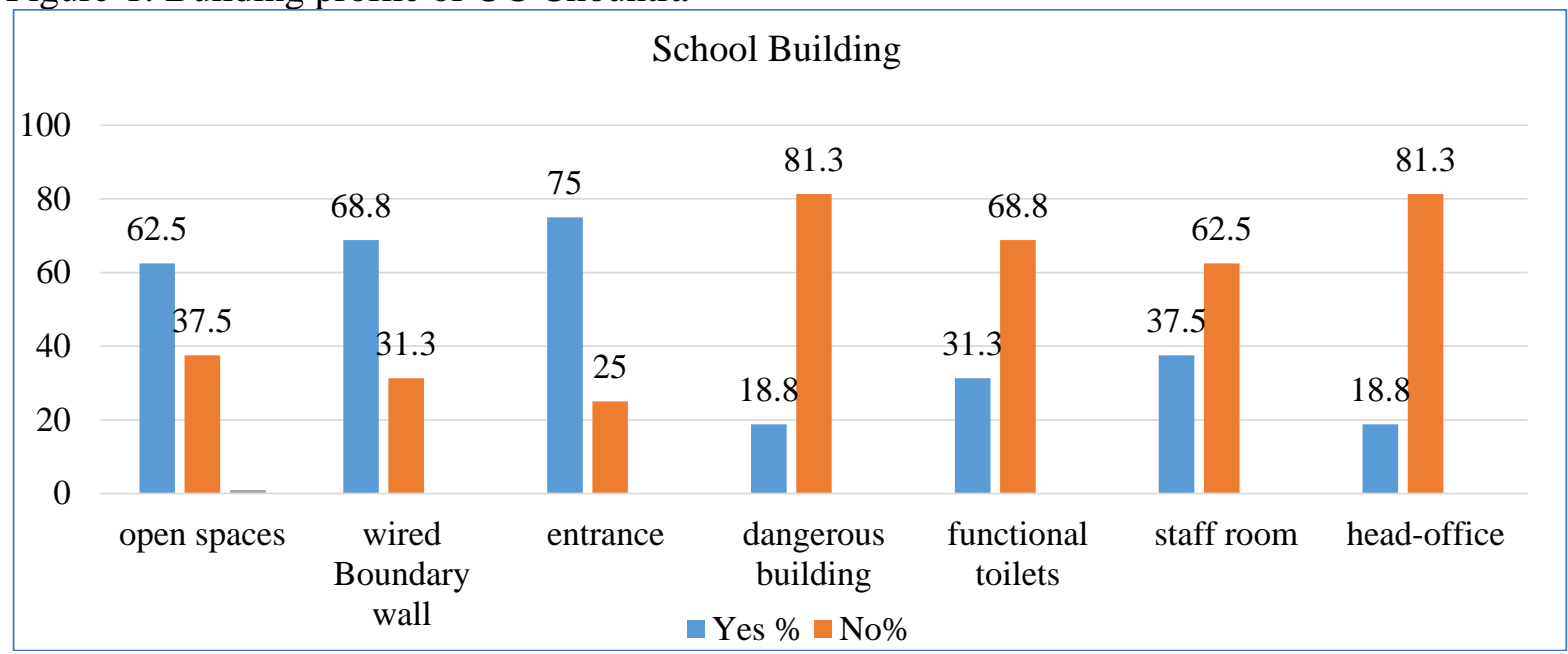

The figure-2 illustrated the condition of the classroom in UC Chountra. It is deduced from the graph that there are airy windows in the classroom with $100 \%$ response. As the graph depicts, $25 \%$ of respondents said that the class size is not appropriate, $6.3 \%$ viewed there is no control of noise, and $37.5 \%$ of respondents highlighted the unavailability of sunlight. However, the overall condition of classrooms is adequate. Qualitative data reveals that, the majority of participants of the study were not satisfied with the condition of the school building due to few and bad conditions of toilets. They agreed that the majority of the schools have no proper playground for students, staff room for teachers, and office for the head of the institution. Majority of the participants were of the view that although there are airy windows in the classrooms, however, it is difficult to teach two classes in one room. One of the participants said that it creates disturbance and produces noise while teaching. They also viewed that certain buildings are not in appropriate conditions.

Figure-2: Classrooms situation and facilities

\section{Condition of Classrooms}

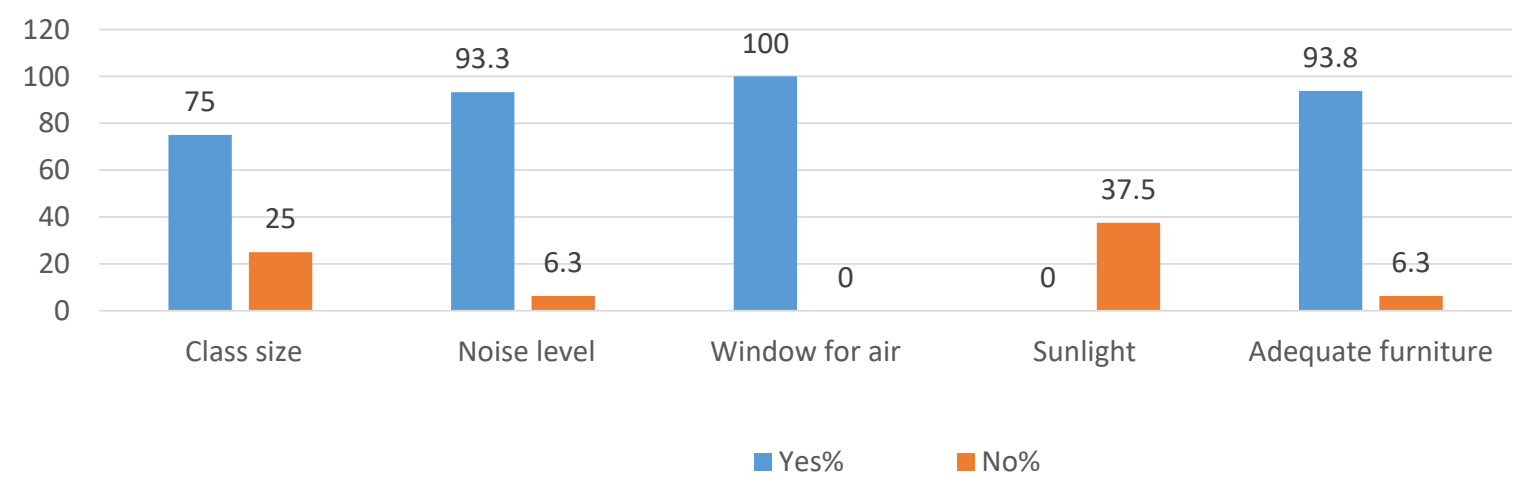

The figure-3 illustrated the condition of school furniture and availability of computer facility in UC Chountra. About $43.8 \%$ of the respondents agreed that the furniture need maintenance, $18.8 \%$ showed that furniture was not moveable. Around $12.5 \%$ of respondents held the view that furniture for staff is not adequate, and $75 \%$ of respondents stated that there is the unavailability of computers for instructions and 56.3\% stated about the lack of internet access. However, all $100 \%$ of respondents were agreed that clean drinking water is available in their 
school. Participants of the study were asked in interviews to share their views regarding school furniture and computer facilities. Three of the participants shared the same views that furniture need maintenance, however, all of them were agreed that furniture is not moveable and cannot meet the need of special students. All the participants were of the view that they have just a few computers in their school and they are not utilizing them for instructional purposes. Participants also agreed that they have no internet facility in their school.

Figure-3: School furniture and computer facilities

School Furniture and Computer Facility

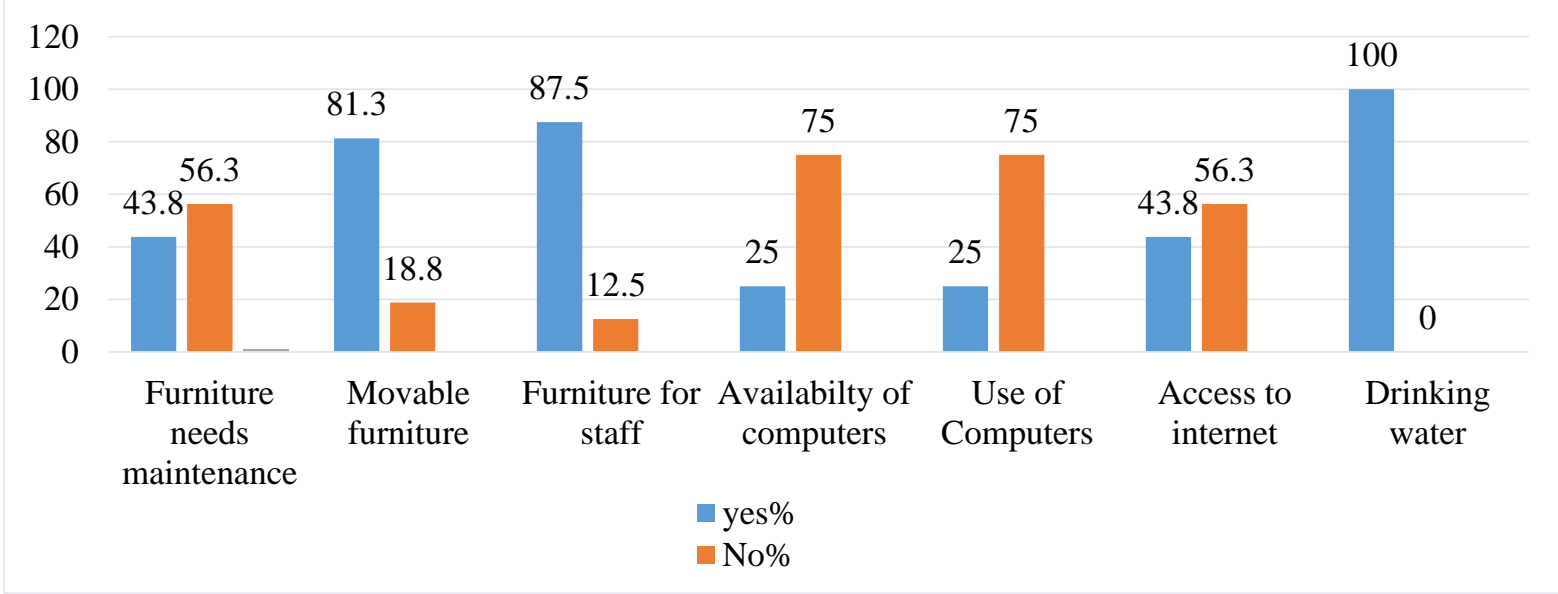

The figure- 4 illustrated the availability of basic human needs in UC Chountra. About $50 \%$ of the respondents said that guard is available for security while $25 \%$ said that sports teacher is working in school and $75 \%$ respondents highlighted that sports teacher is not working in their schools. Around $43.8 \%$ responded that there is no availability of well-managed playgrounds.

Figure-4: Situation of basic human needs sport activities

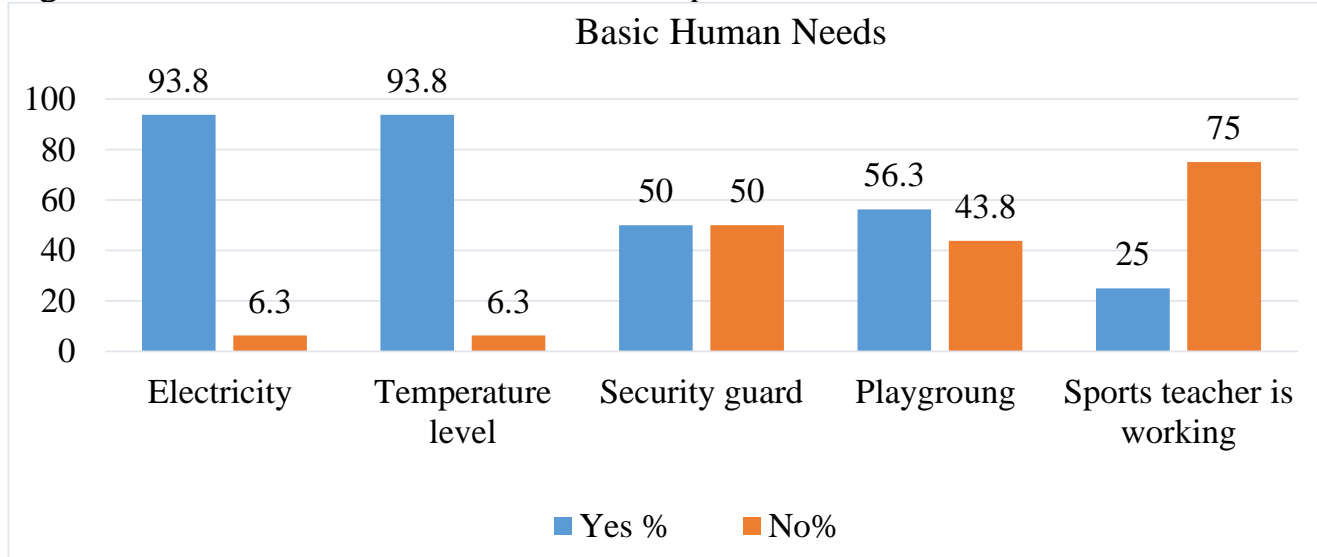

The figure-5 illustrated the usage of learning material for teaching in UC Chountra. About $75 \%$ of respondents said that facilities are not available for special students, $68.8 \%$ said that special equipment is not used to teach students with special needs. $56.3 \%$ said that library material is relevant and used by teachers and students. In qualitative data, majority of the participants were of the view that the school had no facility to meet the needs of the students. There is no special equipment and AV aids in the schools that could be used for special students. One of the 
participants viewed that "students with special needs not be adjusted in the mainstream schools because we have to cover the syllabus and show the results and usually suffer because of these students" Four of the participants said that there is no setup of the proper library that teachers or students can use in the teaching-learning process. All the participants highlighted that classroom walls are adequate to display students' work, however, they were of the view that there is not enough space in classroom for conducting any activity that is why they just focus on teacher-centred teaching method.

Figure-5: Use of learning material for teaching

\section{Learning Material for Teaching}

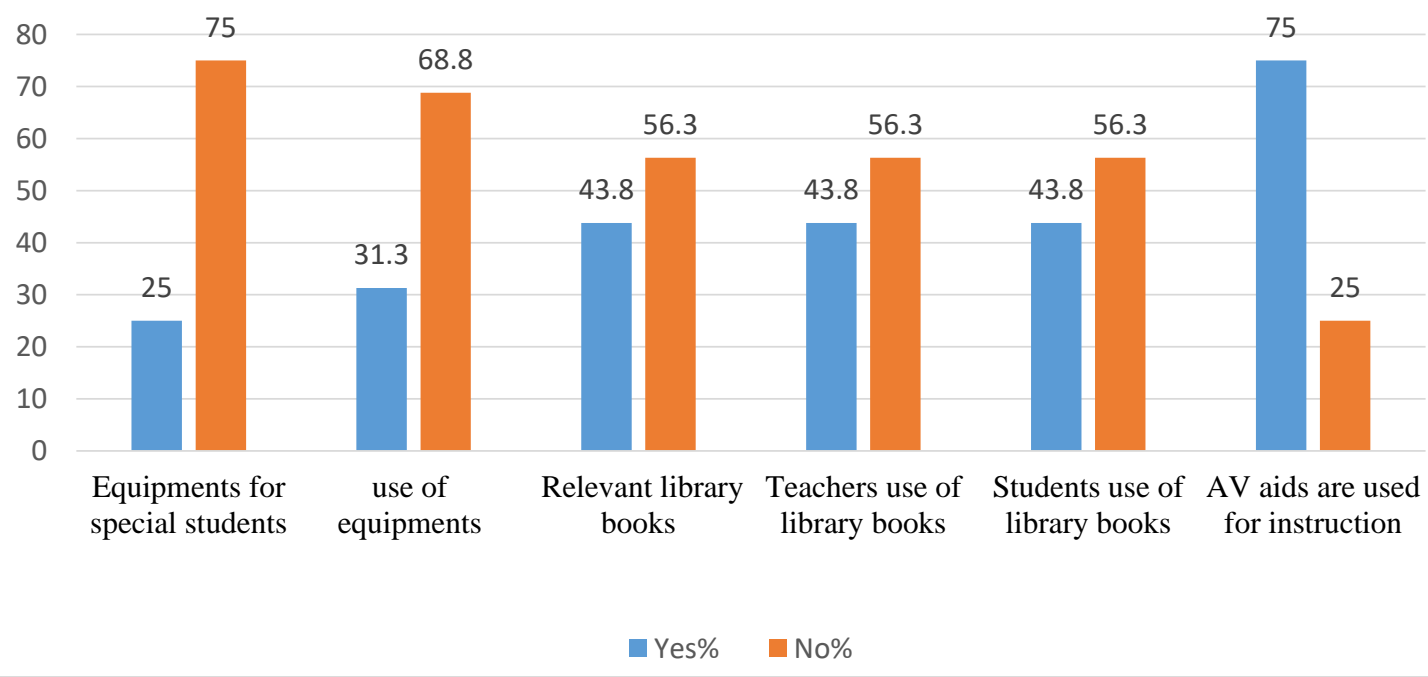

\subsection{Community school partnership}

Likert scale was used to identify community-school partnerships. The questionnaire consists of different constructs that include: parenting and awareness about the role of $S C$, volunteering, learning at home, the role of school for community development, and communityschool collaboration. Descriptive statistics were applied to calculate the percentage and mean score. Based on the scores on the scale which were from 1-4, it was estimated that on a continuum from 1 to 4 mean 3 or above shows a high level of agreement and acceptable while below 3 shows a low level and is not acceptable. The table- 3 reveals that respondents are aware of the functions of SC, and it is also operative in school. Its meetings are organized regularly and minutes are recorded. The mean value of all the items is above 3 that is acceptable.

Table-3: Awareness about the role of school council

\begin{tabular}{clccccc}
\hline S.no & Items & NAA & VL & TSE & TGE & Mean \\
\hline 1 & Aware of the functions of SC & 6.3 & 00 & 31.3 & 62.5 & 3.50 \\
2 & SC is operative in our school & 6.3 & 00 & 00 & 93.8 & 3.87 \\
3 & SC meeting are regularly conduced & 00 & 00 & 18.8 & 81.3 & 3.81 \\
4 & Meeting minutes are recorded & 00 & 00 & 6.3 & 93.8 & 3.93 \\
\cline { 2 - 6 } 5 & The aggregate mean of the table relating to awareness about SC & & 3.8 \\
\hline
\end{tabular}

\subsubsection{Awareness about the role of SC}

The participants of the study were asked whether they were aware of the role of SC. Three of 
the participants shared that they even do not know about any SC working in their school. All the participants shared the same view that they even not got any training to perform the role for SC. Participants also agreed that no meeting of SC held in their school on regular basis. According to the views of participants, SC needs to be restructured and they need training. The table-4 shows that respondents of UC Chountra were of the view that they need training as the aggregate mean value was found 2.5. The lowest mean value was 1.93 that required restructuring of SC according to the views of respondents.

Table-4: Training to perform functions of school council

\begin{tabular}{clccccc}
\hline S.no & Items & NAA & VL & TSE & TGE & Mean \\
\hline 6 & Got training to perform my role effectively in SC & 37.5 & 12.5 & 12.5 & 37.5 & 2.50 \\
7 & Duration of training was sufficient enough & 31.5 & 00 & 37.5 & 31.5 & 2.68 \\
8 & Topics covered in training are need of the participants & 31.5 & 00 & 31.5 & 37.5 & 2.75 \\
9 & The resource person was competent to conduct training & 25 & 00 & 25 & 50 & 3.00 \\
10 & SC need to be restructured & 50 & 12.5 & 31.5 & 6.3 & 1.93 \\
\cline { 2 - 6 } 11 & Aggregate mean of the table relating to training & & & & 2.5 \\
\hline
\end{tabular}

Table 5 shows that majority of respondents were of the view that the community did not provide any support in the provision of books (mean value: 1.87 ); in the provision of furniture (mean value: 1.43); provision of building material (mean value: 2.00 ); in the provision of funds (mean value: 2.12 ); in teaching different subject (mean value: 1.37); in running library (mean value: 1.31), in the provision of accommodation (mean value: 2.2). Aggregate mean (2.22) showed that there is no support of the community and school council for academic and development activities of schools. Qualitative data support quantitative data as, one of the participants viewed that "majority of parents do not contact school because of repeated calls from the school side because of job engagements or agriculture work activities."

Table-5: Community and SC support for academic and development activities of schools

\begin{tabular}{|c|c|c|c|c|c|c|}
\hline S.\#. & Items & NAA & VL & TSE & TGE & Mean \\
\hline 12 & Observed positive changes after establishment of SC & 6.3 & 00 & 25 & 68.8 & 3.62 \\
\hline 13 & Members of PTA/SC create administrative problems & 62.5 & 12.5 & 18.8 & 6.3 & 1.68 \\
\hline 14 & Teaching process is affected during PTA/SC meetings & 81.3 & 6.3 & 12.5 & 00 & 1.31 \\
\hline 15 & Community support in provision of books & 56.3 & 6.3 & 31.3 & 6.3 & 1.87 \\
\hline 16 & ity support in provision of furniture & 75 & 12.5 & 6.3 & 6.3 & 1.43 \\
\hline 17 & ig materials & 43.8 & 18.8 & 31.3 & 6.3 & 2.00 \\
\hline 18 & omr & 37.5 & 18.8 & 37.5 & 6.3 & 2.12 \\
\hline 19 & om & 68.8 & 25 & 6.3 & 00 & 1.37 \\
\hline 20 & oms & 50 & 18.8 & 18.8 & 12.5 & 1.93 \\
\hline 21 & om & 81.3 & 6.3 & 12.5 & 00 & 1.31 \\
\hline 22 & achers & 50 & 6.3 & 37.5 & 6.3 & 2.00 \\
\hline 23 & ers & 18.8 & 12.5 & 18.8 & 50 & 3.00 \\
\hline 24 & line & 00 & 12.5 & 56.3 & 31.3 & 3.18 \\
\hline 25 & $\begin{array}{l}\text { Community support to encourage their children } \\
\text { specially girls to get education }\end{array}$ & 00 & 12.5 & 37.5 & 50 & 3.37 \\
\hline 26 & Com. support in provision of counselling to students & 25 & 00 & 25 & 50 & 3.25 \\
\hline 27 & \multicolumn{5}{|c|}{$\begin{array}{l}\text { Aggregate mean of table related to community and SC support for academic and } \\
\text { development activities of schools }\end{array}$} & 2.22 \\
\hline
\end{tabular}

The percentage of participant responses and aggregate mean (3.2) shows in table 6 that they are satisfied with the role of school playing for community development except with the statement that School allows the community to make use of their playgrounds for games (2.43) 
and cultural activities (2.50). The community members were asked about the role of school in community development. They shared that the school did not allow using of their playgrounds for games and cultural activities. Four participants said that school is neither playing any role to educate parents about daily living skills nor giving any information to parents on creating a "learning-friendly" environment at home. All the participants highlighted that School did not educate the community about important special issues (Child labour, child abuse, harsh behaviour, drug addiction, etc.).

Table-6: Role of school for community development

\begin{tabular}{|c|c|c|c|c|c|c|}
\hline S.\#. & Items & NAA & VL & TSE & TGE & Mean \\
\hline 28 & $\begin{array}{l}\text { School allows the community to use school playground } \\
\text { for games }\end{array}$ & 37.5 & 12.5 & 18.8 & 31.3 & 2.43 \\
\hline 29 & $\begin{array}{l}\text { School allows community to use school building for } \\
\text { cultural activities }\end{array}$ & 31.3 & 18.8 & 18.8 & 31.3 & 2.50 \\
\hline 30 & $\begin{array}{l}\text { School educates community about important and special } \\
\text { issues (child labour, child abuse, harsh behaviour, drug } \\
\text { addiction etc.) }\end{array}$ & 00 & 6.3 & 18.8 & 75 & 3.68 \\
\hline 31 & School educates parents about daily living skills & 6.3 & 6.3 & 18.8 & 68.8 & 3.50 \\
\hline 32 & $\begin{array}{l}\text { School consults parents about learning difficulties of } \\
\text { students }\end{array}$ & 00 & 6.3 & 18.3 & 75 & 3.68 \\
\hline 33 & $\begin{array}{l}\text { School gives parents ideas and information on creating } \\
\text { "learning-friendly" environment. }\end{array}$ & 6.3 & 6.3 & 18.8 & 68.8 & 3.50 \\
\hline 34 & \multicolumn{5}{|c|}{ Aggregate mean of table related to role of school for community development } & 3.2 \\
\hline
\end{tabular}

Table-7 shows that respondents were satisfied with the communication held between school and community. Respondents agreed that School-community schedules parent-teacher-student conferences to monitor student progress. It was further identified that schools inform parents how and when they can reach teachers during and beyond the school day to talk about their child's learning. The mean value of all the items is above 3 that is acceptable. However, respondents highlighted the need to trains school staff on the value of and need for building effective communication between parents and the community (2.93). The respondents agreed that the school-community did not schedule parent-teacher-student conferences to monitor student progress. Four of the participants shared that the school did not give families information about skills required for their children in each subject.

Table-7: Communication between school and community

\begin{tabular}{|c|c|c|c|c|c|c|}
\hline S.\#. & Items & NAA & VL & TSE & TGE & Mean \\
\hline 35 & $\begin{array}{l}\text { School-community schedules parent-teacher-student } \\
\text { conferences }\end{array}$ & 00 & 00 & 25 & 75 & 3.75 \\
\hline 36 & $\begin{array}{l}\text { Inform parents how and when they can reach teachers } \\
\text { during and beyond the school day }\end{array}$ & 00 & 00 & 43.8 & 56.3 & 3.56 \\
\hline 37 & $\begin{array}{l}\text { Provides ways for parents to share school programs and } \\
\text { activities through mobile and oral communication }\end{array}$ & 00 & 6.3 & 31.3 & 62.5 & 3.56 \\
\hline 38 & $\begin{array}{l}\text { Train school staff on the value of and need for building } \\
\text { effectives communication }\end{array}$ & 6.3 & 25 & 37.5 & 31.3 & 2.93 \\
\hline 39 & Aggregate score of table related to communication betwe & schor & & $\mathrm{mm}$ & ity & 3.45 \\
\hline
\end{tabular}

Table-8 shows that respondents agreed with the statements about school support for learning at home. Respondents were of the view that school provides families information about how to keep track of, discuss and support schoolwork at home (3.56); school gives families 
information about skills required for their children in each subject (3.75). The mean value of all the items is above 3 that is acceptable.

Table-8: School support for learning at home

\begin{tabular}{clccccc}
\hline S.No. & Items & NAA & VL & TSE & TGE & Mean \\
\hline 40 & $\begin{array}{l}\text { School provides families information about how to } \\
\text { keep track of, discuss and support schoolwork }\end{array}$ & 6.3 & 6.3 & 12.5 & 75 & 3.56 \\
41 & $\begin{array}{l}\text { School gives families information about skills } \\
\text { required for their children in each subject }\end{array}$ & 00 & 00 & 25 & 75 & 3.75 \\
42 & $\begin{array}{l}\text { School makes families aware of resources and } \\
\text { programs in the community that promote learning }\end{array}$ & 00 & 12.5 & 25 & 62.5 & 3.50 \\
43 & $\begin{array}{l}\text { The school staff is open to suggestions from } \\
\text { community to promote learning }\end{array}$ & 00 & 00 & 50 & 50 & 3.50 \\
\cline { 2 - 7 } & Aggregate score of table related to school support for learning at home & & 3.6 \\
\hline
\end{tabular}

Table-9 shows that respondents agreed that parents play their role to improve school results (3.81) and increasing the admission rate (3.00). The mean value of all the items is above 3 that is acceptable. However, it is identified from the data that Parents are not playing their role to check the dropout rate (2.62).

Table-9: School support for volunteering services

\begin{tabular}{|c|c|c|c|c|c|c|}
\hline S.\#. & Items & NAA & VL & TSE & TGE & Mean \\
\hline 45 & Parents play their role to improve school result & 00 & 00 & 18.8 & 81.3 & 3.81 \\
\hline 46 & Parents play their role to increase admission rate & 00 & 37.5 & 25 & 37.5 & 3.00 \\
\hline 47 & Parents play their role to check the dropout rate & 18.8 & 25 & 31.3 & 25 & 2.62 \\
\hline 48 & $\begin{array}{l}\text { School schedules events at different times of the day } \\
\text { and evening so all parents can attend }\end{array}$ & 6.3 & 12.5 & 25 & 56.3 & 3.31 \\
\hline 49 & School trains volunteers so their time is used effectively & 6.3 & 6.3 & 43.8 & 43.8 & 3.25 \\
\hline 50 & School recognizes volunteer for their time and efforts. & 00 & 6.3 & 37.5 & 65.3 & 3.50 \\
\hline 51 & $\begin{array}{l}\text { School encourages families, students and community to } \\
\text { be involved with the school in a variety of ways. }\end{array}$ & 6.3 & 6.3 & 43.8 & 43.8 & 3.25 \\
\hline 52 & $\begin{array}{l}\text { School provides opportunity to work with local } \\
\text { business, parks, museums, libraries and civic groups to } \\
\text { enrich students and adult learning and skills. }\end{array}$ & 00 & 6.3 & 37.5 & 56.3 & 3.50 \\
\hline 53 & Aggregate mean score & & & & & 3.28 \\
\hline
\end{tabular}

\subsubsection{Causes of dropout}

Teachers elaborated that poor infrastructure, insufficient teaching staff, corporal punishment are the problems faced by government schools that are the cause of the dropout. Few teachers mentioned that migration of families toward city areas and poverty is also one of the causes of leaving school. Other problems include lack of clean drinking water, teaching and learning aids, and cooperation from parents are the major problems of government schools.

The teachers suggested that there should be door-to-door visits to convince parents to send their children to government schools. They also suggested the provision of sufficient teaching staff, subject specialist teachers, cooperation of parents and the community to increase the admission rate in government schools. They suggested that government should provide the necessary learning facilities and equipment in government schools so the parents and children may be attracted to take the admission and stay there. 


\section{Discussion and findings}

Quantitative and qualitative results are corroborated to discuss the problems and the extent of community-school partnership and conditions of elementary schools in UC Chountra. It revealed that toilets were available but mostly not in working condition. Separate office for the school-head and staffroom for teachers were also not available. Unavailability of the resources are recognized, it is the responsibility of the government and also guaranteed in the 1973 constitution of Pakistan to work more diligently in the provision of the required accessories to the primary schools, but it could not be materialized due to financial crunch and education as the least priority (UNESCO, 2007).

Community support and partnership in facilitating schools in the provision of books, furniture, and funds were also missing. It is confirmed by the studies conducted by Gregoric (2013); Okenwa \& Igbo (2013); Epstein (2010); Aguba (2009); Okwor (2008); Cole (2007) that efficient functioning of primary schools without parental and Community Partnership (CP) is not possible. The Well-being, education, and proper development of a child depends on the engagement of the community that is missing in the primary schools of Pakistan. It is a big challenge for academic, managerial, and financial matters of primary schools that consequently affects the improvement of primary education.

The respondents also emphasized the need for a sports teacher and functional playgrounds for the exercise and physical development of the students. It is a famous saying that a sound body has a sound mind. The rush of communities to cities in the majority of the developing countries has left very little space for the playgrounds (Nasira, 2010; Khan, 2003; UNESCO, 2007). It may negatively influence not only the physical but also intellectual development of the primary grade students, and consequently increase the rate of children dropout from schools (Okenwa \& Igbo,2013; Okwor, 2008; Cole, 2007). Pakistan has yet to achieve the target of universalization of primary education and almost 20 million primary age children are out of schools (Economic Survey Report, 2019).

The availability and use of library books were also contradicted at the qualitative phase in comparison to the quantitative analysis of the study. Teachers and students are not found visiting the libraries for reading books. The community support is neither harnessed nor done in the provision, managing, and utilization of library resources. Volunteering role on the part of SC and community to collect books from individuals and organizations for the school library and organizing seminars to promote reading culture in teachers and students were also missing. According to Gregoric (2013) and Epstein (2010), training for volunteering services for the SC and community is essential that establish confidence-building measures for the community to participate in the academic and administrative activities of the school. It is almost non-existent in primary schools of Pakistan because teachers and community are at the opposite end of the partnership and severely lacking confidence in each other.

Reasons for leaving government schools are lack of trust of parents due to teachers' absenteeism, incompetency, lack of cleanliness, and use of corporal punishment, migration of families toward cities, and teachers' lack of commitment. These facts and figures signal the neglect of the rural schools in terms of the provision of basic infrastructural needs from the Government side. Apart from the government support, sustainable school improvement is not possible without the participation of the local community and stakeholders in decision-making in the best interest of children (UNESCO, 2007). According to Epstein (2010); Georgiou, 
(2007); Adams et al. (2009), parental involvement means active participation in the process of educating their children. It is awareness of, and achievement in, school work, an understanding of the interaction between parenting skills and learner success in schooling, and a commitment to consistent communication with educators about learner progress. It may help to check teacher absenteeism, learning difficulties, and corporal punishment (Makgopa \& Mokhele, 2013; Mncube, 2010). Lack of participation on the part of the community in primary schools may bring forth teacher absenteeism, poor parenting skills, unawareness about child developmental needs and learning difficulties.

The quantitative data established that the $\mathrm{SC}$ is operative in conducting regular meetings, and also SC members are trained and competent enough to perform their role in facilitating school in academic, logistic financial support activities. However, at the qualitative phase, participants shared that they even don't know about any SC working in their schools. They viewed SC is required to be restructured and staff is required to be trained. According to Epstein (2010), when SCs are in existence for three years and supported with training, they increase the community involvement in school and thus influence the quality and quantity of family and community connections in the school. The schools are representative of the community and a positive relationship between the both has utmost importance for their development (Cole, 2007; Okenwa \& Igbo, 2013; Okwor, 2008). The same type of situation has been identified in some Asian and African countries where policies and program initiatives exist only on paper not on the ground (World Bank, 2006).

Quantitative data revealed that school administration through the platform of SC communicate and arrange parent-teacher-student conferences to monitor student progress, inform parents how and when they can reach teachers during and beyond the school day to talk about their child's learning. However, qualitative data highlighted that schools did not provide ways for parents to share school programs and activities through mobile messages and oral communication. The phenomena presented in the study about the communication blockade among the community, parents, and school does not only exist in Pakistan but also the grim realities of the majority of the developing Asian and African countries. It is required to be addressed by taking realistic policy measures supported by follow-up supervisory and monitoring mechanisms (World Bank, 2006).

Moreover, the participants said that school is neither playing any role in educating parents about the daily living skills nor giving any information to parents on creating a "learningfriendly" environment at home. It is required that the community leaders (parents, religious leaders, local body's representatives, PTA) and teachers may realize the importance of community resources and input for the effective functioning of the school plant, and cooperate for the wellbeing, education, and proper development of the child. According to Aguba (2009); Ngoka (2003); Nwangwu (2007); Okwor (2008); without building partnership between school and community that may enhance parenting, communication, volunteering, learning at home, decision making and collaborating with the community; effective functioning of primary schools will be very difficult that consequently creates problem in the process of development and well-being of students.

\section{Conclusion and recommendations}

The study concluded that schools are not fully successful in increasing the retention rate for the universalization of elementary education. The reasons behind leaving government schools 
are mainly lack of trust of parents due to teachers' absenteeism, incompetency, lack of cleanliness, use of corporal punishment, migration of families toward cities, and teachers' lack of commitment. These facts and figures signal the neglect of the rural schools in terms of the provision of basic infrastructural needs from the Government side. The study also concluded that, apart from government support, sustainable school improvement is not possible without the participation of the local community and stakeholders in decision-making in the best interest of children. Parental involvement is mandatory, it means that, active participation of parents in the process of educating their children. Parents must have the awareness of, school work, an understanding of the interaction, and a commitment to consistent communication with educators about learner progress. It may help to check teacher absenteeism, learning difficulties, and corporal punishment. Lack of participation on the part of the community in primary schools may bring forth teacher absenteeism, poor parenting skills, unawareness about child developmental needs, and learning difficulties.

The findings of the study recommends that SC may be restructured to utilize formal and informal channels of communication in bringing school and community closer to each other for the efficient functioning of primary schools and promoting education of communities. The sensitization campaign and seminars are suggested to be arranged frequently to find out the ways to enhance parenting, communication, learning at home, and volunteering for building effective collaboration and partnership between primary schools and universities. For this purpose, immediate policy measures are suggested to be taken, and its implementation may be ensured through collective social participation of the community, parents, teachers, and community representatives.

\section{References}

Adams, C. M., Forsyth, P. B., \& Mitchell, R. M. (2009). The formation of parent-school trust: A multilevel analysis. Educational Administration Quarterly, 45(1), 4-33. https://doi.org/10.1177\%2F0013161X08327550

Aguba, C. R. (2009). Educational administration and management: Issues and perspectives. Enugu: Tons and Tons PDS Publishers.

Ahmad, S. M., \& Ullah, O. (2014). Parent-teacher councils in public secondary schools in Northern Pakistan: A qualitative case study. Journal of Applied Environmental and Biological Sciences, 4(7S), 121-134. https://www.textroad.com/pdf/JAEBS/J.\%20Appl.\%20Environ.\%20Biol.\%20Sci.,\% 204(7S)121-134,\%202014.pdf

Ayub, F. (2001). A study of measuring students' achievement in relation to parents' involvement. Fatima Jinnah Women University.

Bibi, R. (2011). Role of School Council in the Improvement of Elementary Girls Schools in Rawalpindi. Islamabad, Pakistan: Secondary Teacher Education Department, Faculty of Education. Allama Iqbal Open University (Doctoral Dissertation).

Clarke, V., \& Braun, V. (2013). Teaching thematic analysis: Overcoming challenges and developing strategies for effective learning. The Psychologist, 26(2), 120-123. http://eprints.uwe.ac.uk/21155

Cresswell, J.W. (2013). Research design: Quantitative, qualitative and mixed methods approaches. Sage Publication.

Cole, S. (2007). Tourism, culture and development: Hopes, dreams and realities in East Indonesia (Vol. 12). Channel View Publications. 
Domina, T. (2005). Levelling the home advantage: Assessing the effectiveness of parental involvement in elementary school. Sociology of Education, 78(3), 233249.https://doi.org/10.1177\%2F003804070507800303

Epstein, J. L. (2010). School/family/community partnerships: Caring for the children we share. Phi Delta Kappan, 92(3), 81-96. https://doi.org/10.1177\%2F003172171009200326

Government of Pakistan (2019). Economic Survey Report. Ministry of Finance, Islamabad.

Gregoric, C. (2013). School-community involvement. Mitcham, Australia: Network for International Education and Values Education.

Habib, Z. (2014). Role of school council in the performance of primary level students. Pakistan Journal of Commerce and Social Sciences (PJCSS), 8(1), 24-29. http://hdl.handle.net/10419/188123

Henderson, A. T., \& Mapp, K. L. (2002). A New Wave of Evidence: The Impact of School, Family, and Community Connections on Student Achievement. Annual Synthesis, 2002. https://files.eric.ed.gov/fulltext/ED474521.pdf

Hoover-Dempsey, K. V., Battiato, A. C., Walker, J. M., Reed, R. P., DeJong, J. M., \& Jones, K. P. (2001). Parental involvement in homework. Educational psychologist, 36(3), 195-209. https://doi.org/10.1207/S15326985EP3603_5

Khan, S.R. (2003). Participation via collective action in government and NGO schools in Pakistan. Development in Practice, 13(4), 361-376. https://doi.org/10.1080/09614520320001122419

Lee, J.S., \& Bowen, N. K. (2006). Parent involvement, cultural capital, and the achievement gap among elementary school children. American Educational Research Journal, 43(2), 193-218. https://doi.org/10.3102\%2F00028312043002193

Maguire, M., \& Delahunt, B. (2017). Doing a thematic analysis: A practical, step-by-step guide for learning and teaching scholars. All Ireland Journal of Higher Education, 8(3), 3351-33514 https://ojs.aishe.org/index.php/aishe-j/article/view/335/553

Makgopa, M., \& Mokhele, M. (2013). Teachers' perceptions on parental involvement: A case study of two South African schools. Journal of Educational and Social Research, 3(3), 219-225. http://dx.doi.org/10.5901/jesr.2013.v3n3p219

Mncube, V. (2010). Parental involvement in school activities in South Africa to the mutual benefit of the school and the community. Education as Change, 14(2), 233-246. https://doi.org/10.1080/16823206.2010.522061

Ngoka G.N. (2003). Concept and issues in advanced education administration. University of Nigeria, Nsukka.

Okenwa, G. N., \& Igbo, R. O. (2013). Extent of community participation in the provision of school plant in the administration of public secondary schools in Enugu State. Journal of Educational and Social Research,3(4), 53-58. http://dx.doi.org/10.5901/jesr.2013.v3n4p53

Okwor, R. E (2008). Parent-teacher association's financial \& material support roles in Enugu state secondary school administration. PhD Thesis, University of Nigeria Nsukka.

Prew, M. (2009). Community involvement in school development: Modifying school improvement concepts to the needs of South African township schools. Educational Management Administration \& Leadership, 37(6), 824-846. https://doi.org/10.1177\%2F1741143209345562

Sheng, X. (2012). Cultural capital and gender differences in parental involvement in children's schooling and higher education choice in China. Gender and Education, 24(2), 131146. https://doi.org/10.1080/09540253.2011.582033 
Siraj-Blatchford, I., Sylva, K., Taggart, B., Melhuish, E., Sammons, P. \& Elliot, K. (2004). Intensive case studies of practice across the foundation stage. Paper presented at the 5th Annual Conference of the Teaching and Learning Research Programme, Cardiff, 22-24 November. http://www.leeds.ac.uk/educol/documents/00003934.htm.

Studsrod, I., \& Bru, E. (2009). The role of perceived parental socialization practices in school adjustment among Norwegian upper secondary school students. British Journal of $\begin{array}{lll}\text { Educational } & \text { Psychology, }\end{array}$ https://doi.org/10.1348/000709908X381771

Symeou, L. (2007). Cultural capital and family involvement in children's education: Tales from two primary schools in Cyprus. British Journal of Sociology of Education, 28(4), 473487. https://doi.org/10.1080/01425690701369525

Tolbert, L., \& Theobald, P. (2006). Finding their place in the community: Urban education outside the classroom. Childhood Education, 82(5), 271-274. https://doi.org/10.1080/00094056.2006.10522840

UNESCO 2007. Country Profiles. Paris: United Nations Educational Scientific and Cultural Organization (UNESCO) Institute for https://journals.sagepub.com/doi/abs/10.1177/0741713607302364

World Bank. (2006). From Schooling Access to Learning Outcomes: An Unfinished Agenda. World Bank. https://doi.org/10.1596/978-0-8213-6792-6

Zepatou, V., Loizidou, M., Chaloulakou, A., \& Spyrellis, N. (2016). School facilities and sustainability-related concepts: A study of Hellenic secondary school principals', teachers', pupils' and parents' responses. Sustainability, 8(4), 311. https://doi.org/10.3390/su8040311 
Annexure: Survey Questionnaire

School Name:

UC Name: Village:

Respondent status: (A) Teacher

(B) Community member

(C) Parent

Profile of Respondent:

Age: (A) Between 20-25

(D) Between 35-40

Gender: $\quad$ (A) Male

(B) Between 25-30

(C) Between 30-35

Academic Qualification: (A) BA/BS

(E) 40 and above

(B) Female

Professional Qualification:

(A)

(B) MA

(C) MPhil

(D) $\mathrm{PhD}$

(E) Continued

Profession: (in case of community member):

\begin{tabular}{|l|l|l|l|l|l|}
\hline S.\#. & Item description & NAA & VL & TSE & TGE \\
\hline Awareness about the role of school council & & & & \\
\hline 1 & I know the functions of school council & & & & \\
\hline 2 & School council is operative in our school & & & & \\
\hline 3 & School council conducts meetings regularly in my school & & & & \\
\hline 4 & Meeting minutes are regularly recorded & & & & \\
\hline 5 & I have got training to work in school Council & & & & \\
\hline 6 & Duration of my training is sufficient enough & & & & \\
\hline 7 & Topics covered in the training are need of the participants & & & & \\
\hline 8 & Resource person was competent enough to conduct training & & & \\
\hline 9 & I felt changes after the establishment of PTA/School council? & & & \\
\hline 10 & Members of PTA/school council create administrative problems & & & & \\
\hline 11 & The teaching process is affected during PTA meetings & & & & \\
\hline 12 & School councils need to be restructured & & & & \\
\hline Contributions of community in school development & & & & \\
\hline 13 & Community support in provision of books & & & \\
\hline 14 & Community support in provision of furniture & & & & \\
\hline 15 & Community support in provision of School building- materials & & & & \\
\hline 16 & Community support in provision of funds & & & \\
\hline 17 & Community support in teaching different subjects & & & \\
\hline 18 & Community support in providing scholarship to students & & & \\
\hline 19 & Community support to run school library during working hours & & & & \\
\hline 20 & Community support in providing accommodation to teachers & & & & \\
\hline Contributions of community in maintaining discipline & & & & \\
\hline 21 & Community support in monitoring and supervising teachers & & & \\
\hline 22 & Community support in maintaining school discipline & & & \\
\hline 23 & Community support to encourage their children specially girls to & & & & \\
\hline
\end{tabular}




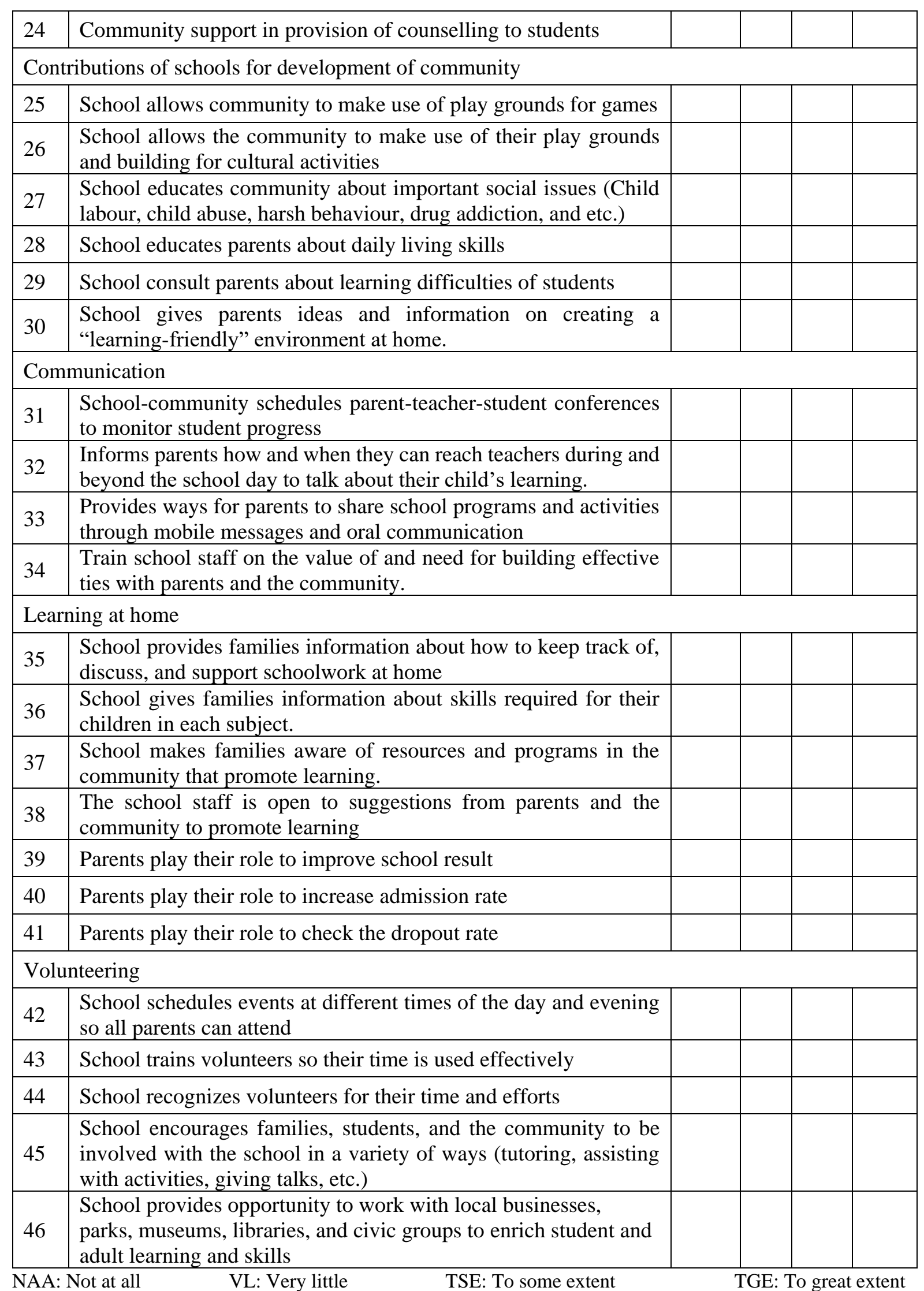

